\title{
Expansion Strategies of European Banks to Brazil and Their Impacts on the Brazilian Banking Sector
}

\author{
Luiz Fernando de Paula* \\ Associate Professor of Economics, State University of Rio de Janeiro and Visiting \\ Research Fellow, University of Oxford's Centre for Brazilian Studies
}

\begin{abstract}
The paper aims to analyse the main determinants of the recent wave of European banks to Brazil as well as the expansion strategies of the major European banks in Latin America, including Brazil. The hypothesis of the paper is that the European banks wave can be understood only if one considers both external and internal determinants. External determinants are concerning to the process of banking consolidation in the European financial system under EMU, that has stimulated somehow some banks to expand abroad. Internal determinants are related mainly to the gradual flexibility of the legal restrictions concerned to the presence of foreign banks in Brazilian banking sector, the price stabilization since 1994, the growth potential of Brazilian banking market, etc. The article also evaluates the impacts of the recent entry of European banks in the retail banking market in Brazil. In this particular concern, it shows that foreign entry has affected the domestic banking market forcing domestic banks to operate more efficiently and also to expand their activities, organically or by acquisitions/mergers. Domestic private banks are still hegemonic in comparison to foreign banks, although relative share of foreign banks has increased a great deal last years.
\end{abstract}

Key-words: multinational bank, European banks, Brazilian banking sector

Resumo: Este artigo objetiva analisar os principais determinantes da recente onda de bancos europeus para o Brasil assim como as estratégias de expansão dos maiores bancos europeus na América Latina, incluindo Brasil. A hipótese do paper é que a onda de bancos europeus somente pode ser entendida se forem considerado ambos os determinantes externos e internos. Determinantes externos referem-se ao processo de consolidação bancária que está ocorrendo no sistema financeiro europeu no contexto do EMU, e que tem estimulado de alguma forma alguns bancos a ser expandirem para o exterior. Determinantes internos estão relacionados principalmente à gradual flexibilidade das restrições legais referentes à presença de bancos estrangeiros no setor bancário brasileiro, ao processo de estabilização de preços desde 1994, ao potencial de crescimento do mercado bancário brasileiro, etc. $\mathrm{O}$ artigo também avalia os impactos da recente entrada de bancos europeus no mercado bancário varejista no Brasil. Neste particular, ele mostra que a entrada de bancos estrangeiros tem afetado o mercado bancário doméstico forçando os bancos locais a operarem de forma mais eficiente e também a expandirem suas atividades, organicamente ou por aquisições/fusões. Bancos doméstico privados são ainda hegemônicos em comparação aos bancos estrangeiros, embora a participação relativa destes últimos tem crescimento bastante nos últimos anos.

Palavras-chave: banco multinacional, bancos europeus, setor bancário brasileiro

JEL classification: G21; G28; G15

*E-mail: $\underline{\text { ffpaula@ax.apc.org }}$ 


\section{Introduction}

The principal aim of this paper is to analyse the main determinants of the recent wave of European banks to Brazil as well as the expansion strategies of the major European banks in Brazil. The hypothesis of the paper is that the European banks wave can be understood only if one considers both external and internal determinants. External determinants are concerning to the process of banking consolidation in the European financial system under EMU, that has stimulated somehow some banks to expand abroad. Internal determinants are related mainly to the gradual flexibility of the legal restrictions concerned to the presence of foreign banks in Brazilian banking sector, the price stabilization since 1994, the growing potential of Brazilian banking market, etc.

The article also evaluates the impacts of the recent entry of European banks in the retail banking market in Brazil. In this particular concern, it shows that foreign entry has affected the domestic banking market in Brazil forcing domestic banks to operate more efficiently and also to expand their activities, organically or by acquisitions/mergers. Domestic private banks are still hegemonic in comparison to foreign banks, although relative share of foreign banks has increased a great deal last years. They have responded to the more competitive environment seeking to become more efficient and participating aggressively in the recent acquisitions and mergers wave, particularly in the privatisation of state-controlled banks.

The paper is divided in five sections, besides this introduction. Section 2 focuses on the process of consolidation in the banking industry, with emphasis on the recent process of European banking consolidation. Section 3 analyses the expansion strategies of the multinational banks. Section 4 examines the determinants of the expansion of European banks in Brazil. Section 5 focuses on the reaction of the big domestic private banks Bradesco, Itaú and Unibanco - to the recent entry of foreign banks in Brazilian banking market. A final section summarises the argument and concludes.

\section{Consolidation in the European banking industry}

The Single Market Programme and European Monetary Union may be seen as reducing the efficiency barriers to cross-borders consolidation within the European Union (EU), and within the subset of nations participating in monetary union, respectively. In fact, these policies can reduce or eliminate differences in currency, regulatory/supervisory structures, and explicit rules against foreign competitors form other EU nations, which should make it easier and less costly for financial institutions to operate across international borders within the EU (Berger, DeYoung \& Udell, 2000, p.9). The Single Market Act ${ }^{1}$ created, in theory, the same opportunities for merger activity and bank concentration that occurred recently in the United States.

The euro, in particular, may play an important role in the EMU area by reinforcing the factors that have been driving the consolidation process in the banking sector. The adoption of a single currency is likely to increase financial institution competition further by reducing entry barriers, by lowering currency risk (reducing the currency conversion

\footnotetext{
1 The Single European Act was implemented in February 1992 creating a single economic marketplace stretching across the EU. The Second Banking Co-ordination Directive, implemented in 1993-94, liberalized the trade of financial services across EU border and introduced banking licence valid throughout the EU.
} 
costs of institutions operating in multiple countries), and by reducing costs to consumers of purchasing services from foreign institutions. Since it lifted the economic barriers to the cross-border supply of financial services within the single currency area, it has the potential to expand the scope for growth and diversification for the area's banks. Thus, the adoption of the euro can reinforce the incentive to create institutions capable of competing effectively on a pan-European scale for corporate banking business. Its influence has strengthened the trend towards larger institutions that would be able to reap the full benefits of greater economies of scale, brought by both increases in the scale of production or by technological progress. (BIS, 2000, p. 134).

As an overall view of the banking consolidation ${ }^{2}$ in the EU over the last decade, we stress below some features of this process, according to information from Belaisch, Kodres, Levy \& Ubide (2001) and Molyneux (2000):

a There is a fall in the quantity of credit institutions in most State Members: all countries, apart Portugal, experienced a decline in the number of banks since the end of the 1980s, but at the same time the number of foreign banks has increased. The reduction in most countries can be attributed to M\&As, but other forms of market exit - such as liquidation - may also have contributed to the decline.

- A common trend cannot be identified in terms of the number of branches, but in many of the largest banking markets (Germany, Italy \& Spain) branch numbers have proliferated during the 1990s. On the other hand, the number of employees declined from 1995 to 1999, particularly in Finland and the UK.

- Market concentration has increased in mostly European countries and in the smaller countries banking systems the five-firm assets ratio typically exceeds $50 \%$ whether measured by total assets, total loans, and total deposits. Consequently, the degree of concentration at the top is particularly striking in the smaller euro countries ${ }^{3}$, where now just a handful of banks dominate the banking sector ${ }^{4}$.

- Although individual euro-area countries' banking systems are becoming more concentrated in consequence of mergers of large institutions, the concentration remains in domestic hands. Foreign bank shares within domestic markets are low within the four largest euro-area economies 5 . They are only significant in Belgium, Ireland and Luxembourg where the market share of subsidiaries of foreign credit institutions as a percentage of the total assets in the end of 1997 was 36.3\%, 53.6\% and $94.6 \%$, respectively.

- Consolidation has accelerated recently at the banking sector's top, since more than half of the 30 greatest euro-area banks are the result of recent mergers and the average size of the top five has doubled since 1995. As a result, the average size of the top 20 euro-area banking groups jumped from US\$ 114,9 billion in 1990 to US\$

\footnotetext{
${ }^{2}$ Consolidation means a merger or an acquisition, whether within a sector or across sector, a process that in general reduces the number of institutions and increases the degree of concentration.

${ }^{3}$ The exceptions are Ireland, Austria and Luxembourg (owning to the presence of many foreign banks).

${ }^{4}$ According to data from Belaisch, Kodres, Levy \& Ubide (2001, p.16), the top five banks have the following market share (in percent of total assets in banking sector) in 1998: 69.5\% in Spain; 51.5\% in Austria; $89.7 \%$ in Belgium; $69.3 \%$ in Ireland; and, $63.3 \%$ in Netherlands.

${ }^{5}$ Foreign bank shares within domestic markets (total assets criteria) were in end-1997, 4.3\% in Germany, 9.8\% in France, $6.8 \%$ in Italy, and 11.7\% in Spain (Idem, 2001, p.17),
} 
321,0 billion in 1999 (Belaisch, Kodres, Levy \& Ubide, 2001, p. 15). Thus, M\&As are changing the structure of the European banking sector.

- There is a decline in net interest margins - the difference between banks' revenues from lending and the remuneration of deposits - in virtually every European banking system, possibly as a result of the increasing competitive pressures on banking sector. De-regulation of the financial services industry in the euro-area over the last 15 years has considerably increased competition in the banking sector and reduced the role of traditional intermediation activities as the principal source of income for banks. In fact, between 1992 and 1998, net interest margin in euro-area (average) has declined from 2.0 to $1.5 \%$ (Belaisch, Kodres, Levy \& Ubide (2001, p.22).

- Consequently, banks have increasingly focused on growing non-interest income sources of earnings, replacing likely interest earnings on most banks' income statements. In UK, Austria, Finland, France and Sweden above or approaching 40\% of banking system gross income was derived from non-interest income sources as at 1996, while in Germany and Norway between $20-25 \%$ of gross income comes from sources of non-interest income, since these countries have more powerful tradition of banks advancing credit to industry and customers (Molyneux, 2000, p.6).

- In the majority of European countries, the overalll trend in the bank efficiency has been downwards, with the exception of Denmark, Finland, Sweden, Switzerland and United Kingdom. In other words, operating costs remain high in European economic area.

- The profitability of the different banks sectors presents a mixed picture although in the majority of countries returns have improved, in spite of the decline in the bank efficiency. The development of non-interest income activities may have had a positive effect on bank's performance, although profitability remains generally lower than in the United States.

Thus, the trend of consolidation has raised concentration levels in The European Economic Area. As a result of the intensified competition, the pace of financial consolidation in Europe accelerated recently, probably in anticipation of the introduction of the new currency. The driving forces of the process of consolidation in EU include, among others, information technology, desintermediation, and the integration of international capital markets, where the creation of the single currency plays a relevant role.

As it can be seen in the Table 1, financial mergers and acquisitions (M\&A) have not been restricted to banking industry lines, but often cross outside the banking lines. In particular, banks have purchased insurance companies, presumably due to the popularity of bancassurance and the absence of legal barriers. However, banking institutions have expanded more actively into other sectors of the financial industry than did other financial institutions into banking business ${ }^{6}$. It also can be seen that mergers and acquisitions remain to a greater extent confined within national borders, contrasting with the small volume of businesses involving other euro country. Thus, there has been significant domestic consolidation for banking institutions as well as expressive M\&A activity

\footnotetext{
${ }^{6}$ As states European Central Bank (2000, p.14), "this may be due to the barriers to entry, historically, being higher in banking than in insurance. It may also be due to the fact that in many Member States the banking industry is far more developed and larger than the insurance industry".
} 
involving securities and insurance firms in EU countries, but little intra-Euro consolidation. Current cross-border activity mostly has taken the form of strategic alliances, often reinforced by the acquisition of minority, non-controlling stakes, as illustrated by the alliance between Banco Santander and Royal Bank of Scotland. Thus, consolidation in the European Economic Area, especially at the retail level, has predominantly prevailed within a national context rather than across border.

TABLE 1

Merger and acquisition activity in the euro-area financial industry (1) - (values in million of US dollars)

\begin{tabular}{|c|c|c|c|c|c|c|c|c|c|c|}
\hline & \multicolumn{2}{|c|}{ Same country } & \multicolumn{2}{|c|}{$\begin{array}{c}\text { Other euro } \\
\text { Country }\end{array}$} & \multicolumn{2}{|c|}{$\begin{array}{c}\text { Other non-euro } \\
\text { country }\end{array}$} & \multicolumn{2}{|c|}{ Total } & \multicolumn{2}{|c|}{ As a percentage (2) } \\
\hline & Number & Value & Number & Value & Number & Value & Number & Value & Number & Value \\
\hline \multicolumn{11}{|c|}{ Banks - banks } \\
\hline 1998 & 7 & 8445 & . & 147 & 12 & 13787 & 20 & 22379 & 12.7 & 13.0 \\
\hline 1999 & 9 & $9 \quad 41242$ & t & 49465 & 15 & 7495 & 28 & 58202 & 15.9 & 34.2 \\
\hline $2000(3)$ & 3 & 4528 & ( & 0 & 5 & 11654 & 8 & 16182 & 26.7 & 62.0 \\
\hline \multicolumn{11}{|c|}{ Banks- non-bank financial } \\
\hline 1998 & 4 & $4 \quad 28604$ & . & 646 & 3 & 897 & 8 & 31147 & 24.2 & 37.9 \\
\hline 1999 & 3 & 320816 & & 800 & 12 & 4130 & 16 & 25746 & 20.8 & 56.4 \\
\hline $2000(3)$ & 8 & 4768 & 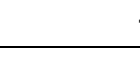 & 11631 & 4 & 653 & 13 & 7052 & 48.1 & 39.1 \\
\hline \multicolumn{11}{|c|}{ Non-bank financial - non-bank financial } \\
\hline 1998 & 6 & 7299 & & 27974 & 7 & 1201 & 15 & 16474 & 11.8 & 13.8 \\
\hline 1999 & 11 & 115508 & rat & 378 & 19 & 21888 & 34 & 37774 & 15.7 & 40.7 \\
\hline $2000(3)$ & 4 & 5071 & & 9 & 5 & 454 & 10 & 5534 & 23.3 & 18.8 \\
\hline
\end{tabular}

Source: BIS (2000, p. 134).

(1) Either acquirer or target company is resident in the euro-area.

(2) Of mergers and acquisitions in all countries.

(3) 1 January to 10 April.

In fact, it seems that there are some impediments to merger and concentration within Europe, and some incentives to such activity outside Europe. One of these incentives can be the absence of a single regulatory agency in the EU, which has limited the benefits to banks of expanding areas of activity across boarders and, at the same time, has prevented European banks from engaging in the diversification of earnings and the reduction in the regulatory capital that has been practiced in US. So, despite of the uniformity that should have been created after the Single Market Act and the various European commission banking and financial directives, and the introduction of a common currency, difficulties, as differing national prudential regulation has done cross border operations hard, since in most EU countries there are still multiple supervisory agencies and, at the same time, there is no co-ordinating agency or single bank regulatory agency for the euro-area ${ }^{7}$ (Kregel, 2001).

Going back to Table 1, one can observe that the number of mergers and acquisitions involving financial institutions among euro country and non-euro country (total of 82 operations involving all sort of financial institutions from January 1998 until April 2000) is bigger even than the transactions within country (total of 54 for the same period). Thus,

\footnotetext{
${ }^{7}$ In fact, as Belaisch, Kodres, Levy \& Ubide (2001, p. 56) states, "the current banking supervisory structure in the euro area is organized along national lines and, as a result of the introduction of the euro, the geographic domain of monetary policy no longer coincides with that of prudential supervision".
} 
there is some evidence of the increasingly importance of the acquisitions outside euro borders in the strategy of some European banks. Particularly important has been the geographic expansion into emerging markets like Latin America, South-East Asia and, at a lesser extension, Central and Eastern Europe. In some extent, expansion has occurred into the emerging countries with which the EU banks have had historical connections, as it seems to be the case of Spanish, Italian and Portuguese banks into Latin America. For the banks that are expanding overseas to increase abroad is not only a source of diversification earnings but also a mean that they have found to strengthen for the competition environment in the euro-area.

\section{The expansion strategies of multinational banks}

The pace of cross-border consolidation of financial institutions has increased last years, and, more recently, has reached the retail banking market. For the purpose of this section, the relevant question is: why banks headquartered in particular countries set up branches or subsidiaries in foreign countries?

The literature from the 1970s and 1980s (Grubel, 1977; Aliber, 1984), generally speaking, built a theory of international banking heavily based on the theory of direct foreign investment in manufacturing, advanced by Kindleberger, Vernon and others. According to this explanation, multinational banks must have some comparative advantages. The basic idea is that multinational banking grows in parallel with the direct foreign investment as the banks try to meet the demand for banking services of these firms overseas. This bank behaviour to move abroad is seen as a defensive attitude necessary to assure the continued business with the domestic parents of the foreign subsidiaries, so that the existing flow of information resulting from the bank-client relationship would not be pre-empted by a competitor bank. Secondarily, multinational service banks also do some business with local and wealthy individuals by offering them specialised services and information required for trade and capital market dealings with their native countries.

The explanation for the motives that a bank expands abroad can be interpreted in price-theoretic terms: "The continuous commercial contacts between the bank and manufacturing firm permit the bank to have access to information about the firm's financial conditions at such a low cost and high speed that it is a better position than any other competitor to evaluate and respond to the firm's demand for loans". So, "the ability to draw on the information and personal contacts between the bank's and manufacturing firm's parents in a [foreign country] at very low marginal cost represents the main source of comparative advantage that the bank's foreign branch has in dealing with the firm's subsidiary abroad in competition with the local banks" (Grubel, 1977, pp. 108-9). From this passage, we can extract that internalisation of information is considered the principal advantage of the multinational bank.

Historically, as stressed by Focarelli \& Pozzolo (2000, p.1, italics added), "the pattern of bank international shareholdings followed that of the economic integration between countries: banks extended their activities abroad in order to provide services to their home-country clients in international transactions; afterwards, with a growing understanding of the foreign market (in particular of regulatory and institutional aspects) and a developed network of relationships with local financial institutions, some banks were induced to increase the range of their operations and provide services to the local population too. Although this account is likely to be accurate in general (...) today the 
actual pattern of bank international shareholdings depends on a wider range of factors than just the overall degree of economic integration between countries".

The recent wave of banking internationalisation, therefore, is characterised not only for financial institutions following their existing relationships, but also (and increasingly) by global banks seeking to amply their activities in the financial markets of the hostcountry mainly through the acquisition of majority, controlling stakes, or acquisition of minority, non-controlling stakes. Thus, the present strategy of global banks aims to diversify their activities in some domestic markets, through a network of branches and greater integration in the local market, while in the past banks strategies aimed mainly to serve their home country (corporate) customers, and also to give some support to domestic firms to access the international financial market. Such new strategy has been, to a greater extent, stimulated by the gradual flexibility or even in some cases by the abolishment of the legal restrictions concerning to the presence of multinational banks in local markets, both in developed and developing countries (Freitas, 1999).

There are few recent works that tries to establish a pattern of expansion of the recent wave of banking internationalisation ${ }^{8}$. The most common explanation is concerning to the effects of the increase in the banking competition caused by the financial deregulation. As margins and fees tighten in the domestic financial services area, financial firms seek to expand overseas to generate higher returns. So, with banks' net interest margins under downward pressure, due the increase of the banking competition, and as the big financial institutions are in general based in mature economies, that is with low potential of growth, some banks are seeking to diversify geographically their activities for markets with potential of growth and/or with greater net interest margins. Generally speaking, banking internationalisation results from the tendency of the increase in minimum scale necessary for a bank remains competitive. Another explanation is that there are potential riskreduction gains from diversification of income from multiple products, client groups and geographies in multi-activity financial services organisations, and that these gains increase with the number of activities undertaken.

Overall, the empirical evidence in the literature (Deminguc-Kunt \& Huizinga, 1998; Claessens et alli, 1998) shows that foreign financial institutions are less efficient than domestic institutions in the developed countries. To analyse this statement, Berger, DeYoung, Genay \& Udell (2000) regarded two hypotheses:

(a) home field advantage hypothesis, under which domestic institutions are generally more efficient than institutions from foreign nations; the advantage is in part due to organizational diseconomies to operating (for instance, turf battles between staff in different nations) or monitoring (it can be difficult to evaluate the behaviour and effort of managers in a distant market) an institution from a distance, or as consequence of other barriers, including differences in language, culture, currency, regulatory/supervisory structures or explicit or implicit barriers against foreign institutions;

(b) global advantage hypothesis, under which some efficiently managed foreign institutions are able to overcome these cross-border disadvantages and operate more efficiently than the domestic institutions in other nations, since they have higher efficiency when operating in other nations by spreading their superior managerial skills or best-

\footnotetext{
${ }^{8}$ There are some few exceptions. See, for instance, Berger, DeYoung, Genay \& Udell (2000) and Focarelli \& Pozzolo (2000).
} 
practice policies and procedures over more resources, lowering costs, or can obtain diversification of risks that allows them to undertake higher risk-higher expected return investments ${ }^{9}$.

Testing these hypotheses in five countries (France, Germany, Spain, UK, US) during the 1990s, Berger, DeYoung, Genay \& Udell (2000) support evidences in favour to a limited form of global advantage hypothesis in which only the efficient institutions in one or a limited number of nations with specific favourable market or regulatory/supervisory conditions in their home countries can operate more efficiently than domestic institutions in other nations. A statistical study made by Focarelli \& Pozzolo (2000) shows - in the same connection with Berger, DeYoung, Genay \& Udell, (2000) - that the banks with crossborder shareholdings are larger and have headquarters in countries with a more developed and efficient market. Banks operating in countries where the banking sector is larger and more profitable should be able to export a superior skill. In particular, local market opportunities - that combines higher expected rate of economic growth, the more stable economic conditions and the bank's inefficiency in the destination country - are the main determinant of the bank's decision to expand abroad. Banks prefer to invest in countries where expected profits are larger, owing to higher expected economic growth and the prospect of reducing local banks' inefficiency.

\section{The Expansion strategy of the European banks in Latin America and Brazil}

\subsection{Determinants of the European bank's expansion strategies to Latin America and Brazil}

From the latter section it can be extracted that both from historical-empirical and theoretical-analytical point of view there are strong reasons to believe that it is in operation, to a greater extent as an international phenomenon, a process of consolidation in banking industry, as a result of both financial deregulation and technological changes. The new phase of banking internationalisation is a consequence of this process, in which increasingly the financial institutions seek to diversify their activities - in terms of products and services, and/or geographically - and increase their minimum scale necessary to remain competitive.

Latin America - including Brazil - is one of the regions that are receiving one of the biggest fluxes of foreign direct investment (FDI) in banking sector to emerging countries in the world since the mid-1990s. However, one cannot see the wave of bank's FDI isolate from the general movement of FDI to Latin America during the nineties. Indeed, the Latin America and Caribbean region received record levels of FDI in the nineties, with inflows totalling US\$ 76,7 billion in 1998 that corresponded to around 41\% of the total FDI flows to developing countries. Of these inflows, $42 \%$ was concentrated in a single country, Brazil, the biggest country of the region that since 1996 has been the leading Latin American FDI recipient and second-largest destination among all the developing countries (ECLAC, 2000, p.35-6) ${ }^{10}$.

\footnotetext{
${ }^{9}$ Williams (1997) calls the latter hypothesis as 'ecletic theory', that asserts that multinational banks must have some monopoly advantage to overcome the incumbent's natural advantage.

${ }^{10}$ During the nineties, as a result of the implementation of policies aimed at stabilizing the economy (the Real Plan), the wide-ranging liberalization process which has opened up previously restricted activities to foreign investors, the regional integration policies and extensive privatisations, net FDI inflows to Brazil grew from
} 
Some of the main determinants of the expansion of European banks to Latin America can be summarized:

- The process of restructuring of the banking sector in EMU, as we have already discussed. Expanding abroad for some European banks is not only a source of earnings diversification but also a way that they have found to strengthen their position considering the increase in the banking market competition in the European Economic Area. The European bank's strategy for Latin America may be interpreted as a response to this more competitive environment, in which several factors are eroding income from traditional banking business. The preference for Latin America, and in lesser extent Central and Eastern Europe, is partially due the fact that the Southeast Asia during the second-half of nineties was in crisis, and India and China have their financial system basically closed to foreign banks, so that the main big emerging markets opened to foreign banks were Argentina, Brazil and Mexico.

- In particular, the dynamics of the internationalisation of the Spanish banks since they have been the main players in the recent wave of foreign banks in Latin America. These banks pursued growth strategies based on M\&A before they have launched their internationalisation growth strategy ${ }^{11}$. So, they had reached the stage of 'mature' banks when they decided to expand overseas. In fact, with the implementation of the EMU and the perspective of introduction of the Euro, the larger Spanish banks, in particular Banco Bilbao Vizcaya (BBV), Banco Santander and Banco Central Hispanico (BCH), in order to maintain their competitive position and to defend themselves from the threat of hostile bids by either local and foreign competitors, had to look beyond their natural borders in search of global markets. An initial stage of this process saw a proliferation of alliances and cooperation agreements with other institutions, chiefly within the European Union, while the second phase has involved a fast-paced, aggressive expansion strategy aimed at the main Latin American markets (ECLAC, 2000, p.159) ${ }^{12}$.

- The deregulation process that has been taken place since the beginning of the $1990 s$, and which has made room for the entry of foreign companies into key economic sectors such as banking, telecommunications and utilities. This process has resulted both from the privatisation of state-owned companies - including the privatisation of state-owned banks - and the greater flexibility of the legal restrictions concerning to the presence of foreign banks in the domestic banking sectors.

- The growth potential of banking market in Latin America is much bigger that in Europe, that has a mature banking market. The size of financial system in terms of

less than US\$ 2 billion in the period 1990-1994 to over US\$ 30 billion in the last two years of the decade (ECLAC, 2001, p.25).

${ }^{11}$ The expansion of Spanish banks to Latin America must also be seen in a broader context in which, after a period of structural changes in the economy driven partly by the process of privatisation of state-firms, the major Spanish service firms (transport, telecommunications, energy and financial services) decided to expand abroad.

${ }^{12}$ For an analysis of the expansion strategy of Spanish banks to Latin America, see also Calderón \& Casilda (2000). 
the ratio of M3 to GDP is only $28 \%$ in Latin America, while in the euro area is $77 \%$ and in US, 71\% (Sebastian \& Hernansanz, 2000, p.18). On the other hand, while in Brazil, in 1996, there was in average one banking branch for each 4,500 persons, in Italy there was one banking branch for each 2,900 persons, in German one for 2,000 persons, and in Spain one for 1,100 persons (Penido, 1999, p. 114).

- The Latin American banking sector offers much better prospects for increasing returns to financial institutions, since the intermediation margins with which banks operate in these countries were considerably higher than in the developed world. While the domestic banks' average margin on asset in Latin America was 5.76\% for the period 1988-95 (in Brazil it was 6.6\% and Argentina 9.9\%), while in OECD's countries it was $2.80 \%$ for the same period (Claessens, Demirguç-Kunt \& Huizinga, 1998, p.26).

- The potential gains in efficiency is high in Latin America, since its degree of banking efficiency is in general lower than the efficiency in the developed countries. In fact, the domestic banks' ratio of overhead to asset in Latin America was in average $6.12 \%$ in 1988-1995 while it was $2.60 \%$ in OECD's countries (Idem, p. 26).

In the case of Brazil, internal determinants are probably related to the more stable economic conditions, with the price stabilization after 1994, the higher expected rate of economic growth, and the growth potential of banking market. Besides, since the early 1990s the Brazilian economy has been undergoing a wide-ranging liberalisation process, which has opened up previously restricted activities to foreign investors. In this context, the recent entry of foreign banks is related to the gradual flexibility of the legal restrictions concerning to the presence of foreign banks in the Brazilian banking sector. According to the Article 52 of the Transitory Dispositions Act of the Constitution of 1988, it is prohibited the installation of new agencies for foreign financial institutions as well as the increase of the capital's share of financial institutions based in the country. However, such restrictions did not apply to the authorisations resulting from international agreements, reciprocity, or decisions made in the Brazilian government's interest.

A particularly important regulatory change occurred in 1995, under the banking crisis that resulted from the tightening monetary policy and the consequent raising interest rates to very high levels to face the effects of 1994-95 Mexican crisis. The recent process of banking consolidation in Brazil is somehow similar to Mexican experience in the sense that in both countries the authorities responded to the banking crisis with an array of support programmes for financial institutions and their borrowers. These programmes intended to bolster the health of the financial sector and, at the same time, to open the sector to foreign banks, since the presence of these banks could help to strength the health of the banking sector $^{13}$. Besides, upon deregulation, the entry of foreign banks has been used as a policy to weaken the effect of the local monopolies that had been established under the previous regulatory structure.

In this context, the entry of some foreign banks was allowed by the Brazilian government in order to permit the purchase of some problematic banks - such as Banco Econômico and Banco Bamerindus - and also to strength the national banking sector. The

\footnotetext{
${ }^{13}$ See Dagos, Golberg \& Kinney (2000) for an analysis on the recent foreign bank penetration in Mexico and Argentina.
} 
Legislative Intent ('Exposição de Motivos') no. 311, from 23/8/95, an act from the Brazilian's President, allowed the President exceptionally to authorise, case to case, the entrance of foreign banks in Brazil. This President's norms says that the entrance of foreign bank interests the country, and emphasises the following positive aspects: the increase of the domestic savings; the increase in the operational efficiency of the banking sector; the best and diversified supply of financial services with lowest costs; the introduction of new technologies.

Therefore, Brazilian government has permitted the entrance of a great number of foreign banks in its domestic banking market, going into the direction to the international tendency of expansion of financial conglomerates that are looking for new markets for their businesses. The changes in the regulatory framework concerned to foreign banks, the price stabilisation since 1994, the growing potential of Brazilian retail banking market, the increasing integration of Brazilian economy to commercial and financial flow, all them combined, have attracted the foreign investment to Brazilian banking sector.

\subsection{The Recent European banks wave in Brazil: a picture}

The key factors that have permitted the recent merger movement in Brazil include, as we have already seen, the financial deregulation as a result of the flexibility in the regulatory framework concerning to foreign banks, the 1995-96 banking crisis, since it resulted in openness of the banking sector to foreign banks, and, last but not the least, the price stabilization since 1994 that changed the long-term business landscape in Brazil.

Table 2 shows the acquisitions in Brazilian banking sector during the period 1995-

2000. The main features of the recent M\&A wave in Brazil are:

a) Foreign banks commanded the acquisitions, with the obvious predominance of European banks. Unlike in neighbouring Argentina where foreign bank acquisitions have included two of the largest three private banks, foreign acquisitions in Brazil have involved mainly by medium-sized banks. This partly reflects that the market capitalization of the very largest banks has proved to be prohibitive.

b) The principal foreign acquisitions, in terms of size, were the purchase of Bamerindus by HSBC, that was paradigmatic since involved for the first time a big domestic retail bank, Excel/Econômico by BBVA, America do Sul by Sudameris, Banco Noroeste by Santander, Banco Real by ABN-AMRO, and Banespa by BSCH. The last case was the biggest acquisition done in the last years, since it involved the purchase of a bank with assets in the total amount of around US\$10,0 billion, and permitted that Santander jumped the ranking of

TABLE 2

Principal acquisitions in the Brazilian banking sector - 1995-2000

\begin{tabular}{cll}
\hline \hline Year Acquirer & Origin of acquirer & Institution acquired \\
\hline \hline BSCH & Spain & Banespa \\
2000 Itaú & Brazil & Banestado \\
Bradesco & Brazil & Boavista \\
Unibanco & Brazil & Bandeirantes, Credibanco \\
BSCH & Spain & Meridional/Bozano Simonsen \\
\hline 1999 Bradesco & Brazil & Banep \\
\hline
\end{tabular}




\begin{tabular}{|c|c|c|}
\hline 1998 ABN Amro & Netherlands & Banco Real \\
\hline ABN Amro & Netherlands & Banco Nacional de Pernambuco \\
\hline Itaú & Brazil & Bemge \\
\hline Unibanco & Brazil & Dibens \\
\hline Sudameris & Italy, France, Brazil & América do Sul \\
\hline Chase Manhattan & United States & Patrimônio \\
\hline Bradesco & Brazil & Pontual \\
\hline GE Capital & United States & Banco Mappin \\
\hline CSFB & Switzerland & Banco Garantia \\
\hline BBVA & Spain & Excel-Econômico \\
\hline Caixa Geral de Depósitos & Portugal & Bandeirantes \\
\hline 1997 Santander & Spain & Banco Noroeste \\
\hline Banco Interatlantico & Portugal, France & Boavista \\
\hline Santander & Spain & Banco Geral de Comércio \\
\hline Itaú & Brazil & Banerj \\
\hline Bradesco & Brazil & $\mathrm{BCN}$, Credireal \\
\hline HSBC & United Kingdom & Bamerindus \\
\hline Pactual & Brazil & Sistema \\
\hline Bozano Simonsen & Brazil & Meridional \\
\hline Swiss Bank Corporation & Switzerland & Omega \\
\hline Robert Fleming & United Kingdom & Graphus \\
\hline NationsBank & United States & Liberal \\
\hline American Express & United States & SRL \\
\hline Banco de Crédito Nacional (BCN) & Brazil & Credireal \\
\hline Mellon Bank & United States & Brascan \\
\hline Llyods & United Kingdom & Multiplic, Losango \\
\hline Unibanco & Brazil & Fininvest $(50 \%)$ \\
\hline Icatú & Brazil & Fininvest $(50 \%)$ \\
\hline 1996 Banco de Crédito Nacional & Brazil & Itamarati \\
\hline Cindam & Brazil & Fonte \\
\hline Banque Nacional de Paris & France & Banco Comercial de São Paulo \\
\hline BBA Creditanstalt & Austria & Financiadora Mappin \\
\hline Itaú & Brazil & Banco Francês e Brasileiro \\
\hline Pontual & Brazil & Martinelli \\
\hline Excel & Switzerland & Econômico \\
\hline Sudameris Brasil & Italy/France/Brazil & Financeiro e Industrial de Investimento \\
\hline 1995 Unibanco & Brazil & Nacional \\
\hline Pontual & Brazil & Digibanco \\
\hline
\end{tabular}

Source: Author's ellaboration with information from Chase Manhattan (2000) and Central Bank of Brazil. 
banks to become the third private bank in Brazil. This acquisition was a sort of 'turning point' in the history of $\mathrm{BSCH}$ in Brazil, since prior to the Banespa acquisition in November 2000, Santander do Brasil's relatively modest investments in Meridional and the prestigious investment bank Bozano, Simonsen left the group still locked out of the market elite at number 8 in the banking industry.

c) The big American banks already established in Brazil - Citibank and Bank Boston -, unless until recently, have participated timidly of the wave of acquisitions in Latin America, including Brazil, and opted to grow mainly organically in the Brazilian banking market, where they traditionally have focused their activities on a smaller clientele ${ }^{14}$. The strategy of these banks in Brazil has been to amply their customer's base including segments of middle class and of medium size firms. BankBoston has sought to perform in a more selected segment of retail market, with monthly income up to $\mathrm{R} \$ 4,000$, while Citibank has sought to amply its customers base including low segments of the middle class, with monthly income up to $\mathrm{R} \$ 1,000$, as well as firms with annual revenues up to $\mathrm{R} \$ 5$ million. The timid presence of American banks can be partially explained by the fact that they have obtained a very good profitability with the offer of new products in their own domestic market (United States), where they have been able to expand geographically within the country with the deregulation of the financial system.

d) The three big private domestic banks - Bradesco, Itau and Unibanco - have reacted to the wave of acquisitions by foreign banks, participating actively of the process of acquisitions, with some important purchases, like Nacional by Unibanco, BCN/Credireal by Bradesco, Banerj by Itau and Bandeirantes by Unibanco. Particularly important has been the participation of Itaú in the purchase of state-owned banks, such as Banestado (Paraná), Banerj (Rio de Janeiro) and Bemge (Minas Gerais). In the case of Unibanco and Itaú - with a size smaller than Bradesco, the greatest private bank - their behaviour take the form of a defensive reaction, since they try to maintain their market share and leadership in the banking market, using acquisitions/mergers in order to avoid take-overs.

The increasing presence of foreign banks in Brazil is confirmed by the available data: foreign banks have grown almost six times the national rate in 1995-1999. In terms of market share, banks controlled by foreign financial groups have increased their stake from $8.4 \%$ in $1995,12.8 \%$ in 1997 to $23.2 \%$ in 1999 of the total of the assets in banking sector in just five years, while declines the participation of all other segments, but in special in the public institutions (see Table 3). The increase of foreign banks in Brazil occurred, at a greater extent, on the private domestic banks and, at a lesser extent, on state ${ }^{15}$ and federalbanks. Although there is a declining trend in the relative share of the public banks, including the two 'giants', Caixa Econômica Federal and Banco do Brasil, their relative

\footnotetext{
${ }^{14}$ BankBoston and mainly Citibank's recent acquisitions of local banks or branches in Latin America suggest that the banks' strategies may be changing.

${ }^{15}$ We are considering in this section 'state banks' as banks whose main owners are the government of the Brazilian states, and 'federal banks', the banks whose main owner is the federal government.
} 
share is still majority with around $33 \%$ of the assets in the end of 1999. On the other hand, the major private domestic banks in Brazil have increased their market share in banking sector via acquisitions of state and private-banks and, at a lesser extent, by organic growth. Consequently, the market share (total of assets of both public and private banks) of the top 4 private domestic banks - Bradesco, Itaú, Unibanco and Safra - increased from $23.7 \%$ in 1999 to $27.4 \%$ in 2000, a significant increase of $3.7 \%$ in their market share in only one year (Gazeta Mercantil, 31/3/01, p. B1).

TABLE 3

Market share of the banking sector in Brazil (total assets) - 1993-1999 (\%)

\begin{tabular}{l|r|r|r|r|r|r|r}
\hline \hline Institution & 1993 & 1994 & 1995 & 1996 & 1997 & 1998 & 1999 \\
\hline \hline $\begin{array}{l}\text { Banks with foreign } \\
\text { control }\end{array}$ & 8.4 & 7.16 & 8.39 & 9.79 & 12.82 & 18.4 & 23.2 \\
\hline $\begin{array}{l}\text { Domestic private } \\
\text { banks }\end{array}$ & 40.7 & 41.21 & 39.16 & 39 & 36.76 & 35.3 & 33.1 \\
\hline $\begin{array}{l}\text { Public banks } \\
\text { (+Caixa estadual) }\end{array}$ & 13.4 & 18.17 & 21.9 & 21.92 & 19.06 & 11.4 & 10.2 \\
$\begin{array}{l}\text { Caixa Economica } \\
\text { Federal }\end{array}$ & 14.5 & 14.98 & 16.4 & 16.47 & 16.57 & 17.0 & 17.1 \\
\hline $\begin{array}{l}\text { Banco do } \\
\text { Brasil* }\end{array}$ & 22.9 & 18.28 & 13.91 & 12.52 & 14.42 & 17.4 & 15.8 \\
\hline $\begin{array}{l}\text { Credit } \\
\text { cooperatives }\end{array}$ & 0.1 & 0.2 & 0.24 & 0.3 & 0.37 & 0.5 & 0.7 \\
\hline $\begin{array}{l}\text { Banking } \\
\text { Sector }\end{array}$ & 100.0 & 100.0 & 100.0 & 100.0 & 100.0 & 100.0 & 100.1 \\
\hline \hline
\end{tabular}

Source: Central Bank of Brazil

$\left.{ }^{*}\right)$ Federal banks

\subsection{Expansion strategies of the major European banks}

Graph 1 shows that among the twelve biggest private banks in Brazil, seven banks are foreign ones, including top five European banks - HSBC, ABN-AMRO, Santander (BSCH), Sudameris, and BBV Banco (BBVA) - and two American banks - Citibank and BankBoston, respectively from the groups Citicorp and FleetBoston. The Top 12 private banks get control of $50 \%$ of the total of banking sector's assets (including federal and state banks). The big five domestic private banks all together have $28.9 \%$ of the total of the assets, while the seven big foreign banks have $21.1 \%$. Thus, domestic private banks are still hegemonic in Brazil in comparison to foreign banks, although the relative share of foreign banks has increased a great deal in recent years. Santander, in particular, after the purchase of Banespa, in November 2000, became the biggest foreign bank in Brazil and the third private bank.

There are some common and some distinguish features among the biggest European banks in Latin America (see Table 4). One obvious common feature is that all Top 4 are global and big universal banks, that choose to expand abroad a growth strategy. In 1997, overseas income represented more than $35.0 \%$ of the total revenues of these banks (Nellis et alli, 2000, p.57), and this relative share has been increased in the case of the Spanish banks because of the recent acquisitions in Latin America. As we have seen in the section 
3, the literature on multinational banks shows that banks operating in countries where the banking sector is larger and more profitable should be able to export a superior skill and are therefore more likely to expand their activities abroad. In fact, all the biggest European banks in Latin America - BSCH, BBVA, HSBC and ABN-AMRO - increased recently their market share in their domestic markets via mergers and acquisitions, reaching a top position in these markets ${ }^{16}$.

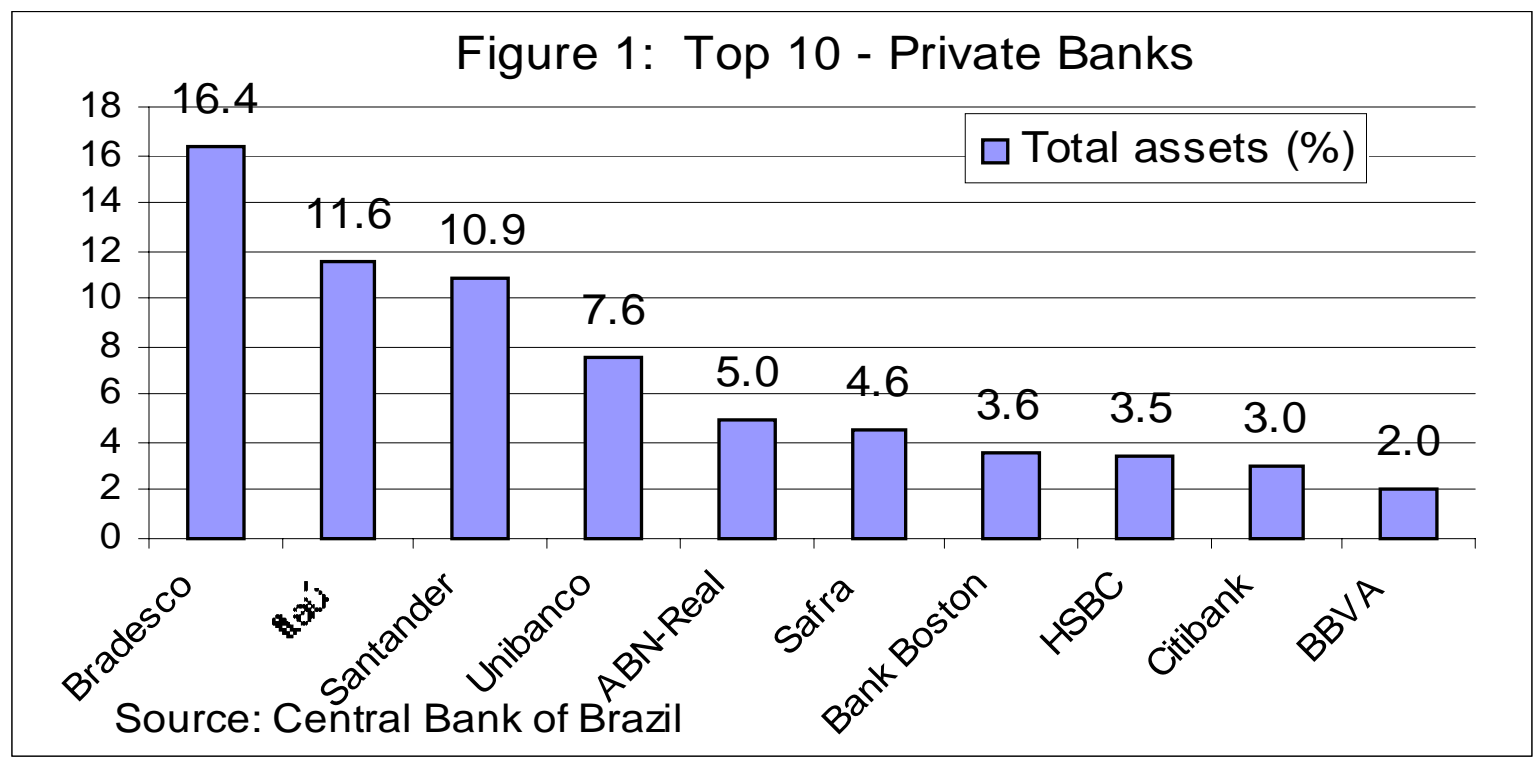

All them are seeking to expand their activities in Europe more recently, as HSBC expansion in France (CCF), and ABN-AMRO in Italy. They are also present in other Latin American countries, but this presence is uneven, as one can see in the Table 5. The total assets of the 20 largest foreign banks in the region is highly concentrated in just three of those banks - BSCH, Citibank and BBVA - which accounted for $44.8 \%$ of the total assets of this group of banks in 1998 (ECLAC, 2000, p. 61). Interestingly, these banks are the only banks in the world to have achieved top positions outside their natural markets. The market share of these banks has increased since they have purchased some big domestic banks after 1998, such as Bancomer by BBVA (June 2000), Serfin (May 2000) and Banespa (November 2000) by BSCH, and Banacci (May 2001) by Citigroup. Besides, they are the only banks with a extensive network in the six biggest countries of the region. ABN-AMRO, although with investment in different Latin American countries, only in Brazil and Chile has somehow a relatively important share in banking market, in particular due the purchase of the Banco Real in Brazil. HSBC has its assets concentrated in the three

\footnotetext{
${ }^{16}$ Only to mention the more recent and important M\&A involving these banks, HSBC bought Midland in 1992, lifting the group's total assets from $£ 86$ billion in 1991 to over $£ 170$ billion in 1992, creating one of the largest financial organisations of its kind in the world; ABN merged with AMRO in 1991 and got the leadership in Netherlands; Santander merged with Banco Central Hispanico (a former merger between Banco Central and Hispanico) in 1999, becoming the largest Spanish financial group; afterwards, BBV (a former merger between Bilbao and Vizcaya) merged with Argentaria, forming the second largest Spanish financial group. Consequently, Spanish banking sector became one of the highly concentrated in Europe, forming a sort of duopoly, with the market share of the two biggest institutions growing from 33\% in 1987 to $50 \%$ in 1996 (ECLAC, 2000, p.158), and increasing even more after the recent mergers.
} 
principal countries of Latin America: Mexico, Brazil and Argentina. It can be note in Table 4 that Citibank became the second biggest foreign bank in Latin America after the purchase of the Mexico's top financial institution, Banacci. Although Citibank has been present in all more important Latin America's countries since a long time, only in Mexico it has the market leadership.

TABLE 4

Biggest foreign banks in Latin America by assets (Sept. 2000) - USD million

\begin{tabular}{llrrrrrrrr}
\hline \hline BANK & Country & Argentina & Brazil & Mexico & \multicolumn{1}{c}{ Chile } & Colombia Venezuela & TOTAL & $\%$ \\
\hline \hline BSCH* & Spain & 26,130 & 28,682 & 20,100 & 30,200 & 1,376 & 2,556 & 109,044 & 33.99 \\
Citibank** & USA & 10,429 & 8,798 & 42,590 & 6,350 & 1,137 & 686 & 69,990 & 21.81 \\
BBVA & Spain & 9,174 & 5,004 & 37,300 & 4,900 & 2,811 & 3,700 & 62,889 & 19.60 \\
BankBoston & USA & 11,350 & 9,315 & 358 & 6,800 & 108 & & 27,931 & 8.71 \\
HSBC & UK & 5,016 & 9,126 & 15,202 & & & & 29,344 & 9.15 \\
ABN-Amro & Netherlands & 2,801 & 15,581 & 154 & 2,900 & 110 & 95 & 21,641 & 6.75 \\
TOTAL & & 64,900 & 76,506 & 80,853 & 51,150 & 5,542 & 7,037 & 320,839 & 100.00 \\
\hline
\end{tabular}

Source: Own elaboration with data from Sebastian \& Hernansanz (2000, p.37); Banco Santander (Banespa-Brazil); and Gazeta Mecantil (Banacci-Mexico) Notes: (*) Including Banespa, with data from November 2000

(**) Including Banacci, with data from December 2000

The really big European investors in Latin America are the two big Spanish banks, which developed recently an aggressive strategy of expansion in the region, and the American bank, Citibank, that has historically a strong and old presence in Latin America. $\mathrm{BSCH}$ and BBVA have together more than US\$170,000 million of assets in Latin America and around $55.8 \%$ of the total assets of the Top 6 in the region (Table 4). BSCH, after the purchase of Banco Serfin in Mexico and Banespa in Brazil, became the biggest private bank of the region, with more than US\$ 100.000 million of assets. BCHS is the leader among the foreign banks in Argentina, Brazil and Chile, while BBVA is the leader in Colombia and Venezuela. The difference in terms of the total assets between BSCH and BBVA in Latin America is due mainly to Brazil, where recently BSCH bought Banespa and BBVA has a small market share.

ABN Amro, in Dutch market, and BSCH and BBVA, in Spanish market, grew a great deal in their domestic market pursuing growth strategies based on mergers and acquisitions and could obtain a top position in their national markets. This policy allowed them to increase their competitiveness and to reach the necessary size that stimulated them to start their internationalisation strategies. After they have consolidated their position in domestic market (and sometimes at the same time) they expanded abroad, probably preparing themselves for the increase in the European competition after-EMU. ABNAMRO, BSCH and BBVA are big banks in small or medium highly concentrated systems that are increasingly expanding their operations to other geographical markets, especially as domestic alternatives are limited ${ }^{17}$. HSBC is one of the largest financial conglomerates in

\footnotetext{
17 The Spanish banks have the advantage to have more cultural affinities with Latin America, and some familiarity with the region, where they have offices since the 1970s. They followed, however, slightly different strategies in the region: Santander put more emphasis on banks with a greater share in investment banks and on the acquisition of large shareholdings from the outset that guaranteed it both ownership and full management control; BBV began its expansion based on small shareholdings - providing the project was large enough - forming partnerships with local banks, which were gradually built-up over time.
} 
the world. Its strategy of 'managing for value' emphasis the group's balance of business between the older, mature and faster-growth emerging countries. ${ }^{18}$.

\section{The reaction of domestic private banks}

\subsection{The effects of the entry of foreign banks in domestic banking markets}

The literature on the effects of entry of foreign banks in domestic banking markets (Deminguc-Kunt \& Huizinga, 1998; Claessens et alli, 1998) shows that generally speaking the foreign entry can have two main features/impacts:

a) First, foreign banks are less efficient than domestic banks in the developed countries, but more efficient than domestic banks in emerging economies. The source of the superior efficiency over domestic institutions in emerging countries is diversified and the list includes the greater stability of the foreign banks, the easier access to foreign sources of funds, the more propitious to innovation of the foreign banks, and, finally, that they have in general a more rigorous supervision in their native country.

b) Second, foreign bank entry can render national banking markets more competitive, and thereby can force domestic banks to operate more efficiently, making them to reduce their operating costs, to expand their activities. It is argued that the benefits of entry in terms of improved financial services and regulation should outweigh the potential costs of entry (cream skimming, foreign market dominance destabilizing rapid outflows of capital). Foreign banks enter niches and introduce new services to exploit opportunities and, doing so, increase competition for domestic banks. To protect previously the existing market power or entrenched management, financial institutions within nations may engage in M\&A to help them to fend off potential foreign competitors.

Carvalho (2001) shows that, according the recent data, there is no clear evidence that foreign banks are more efficient than domestic private banks in Brazil and that foreign bank contributed to a strategic reorientation of the financial activity toward supporting the private sector. Our findings support this hypothesis. On the other hand, there is some evidence that foreign bank entry has rendering banking markets more competitive, forcing private domestic banks to operate more efficiently, at the same time that, as we have seen, the biggest ones have been participating actively of the process of consolidation in the Brazilian banking sector, due to competitive pressure of the foreign banks acquisitions.

In order to measure the cost efficiency of the biggest domestic private banks in Brazil, we use two indicators: (a) operating efficiency, that as the name suggests it is used to measure the operating efficiency of the banks, including both intermediation and norintermediation activities; (b) cost-to-income ratio (expenses/costs), a very usual ratio used to measure the bank's efficiency in its traditional activity of financial intermediation ${ }^{19}$. To measure the performance of the banks it is used two conventional ratios: return on average equity - ROOE (net profit/equity), and return on average assets - ROOA (net profit/total assets). It was not possible to use indicators of labour productivity since the necessary data are not available for a longer period by the Brazilian central bank.

\footnotetext{
${ }^{18}$ According to the Annual Report 2000, the group made $48.2 \%$ of its profit in Asia, 39.0\% in Europe, $9.6 \%$ in North America, and 3.2\% in Latin America in 2000.

${ }^{19}$ The precise definition of these indicators can be seen in the notes of the Table 5 .
} 


\subsection{The recent behaviour of the biggest domestic private banks}

Table 5 presents some indicators of efficiency and performance ${ }^{20}$ of the three biggest domestic private banks - Bradesco, Itaú and Unibanco - for the period 1997-2000, using 'unconsolidated' data ${ }^{21}$. These banks have some common features: they are big retail and universal banks with a large customer base and strong position in the different financial activities (insurance, credit cards, asset management, etc.) what permits them a significant amount of cross-selling activities. Therefore, they are banks with potentiality to reach both scale and scope economies.

\section{TABLE 5}

Indicators of efficiency and performance -top three private domestic banks (\%)

\begin{tabular}{|c|c|c|c|c|c|c|c|c|c|c|c|c|}
\hline & \multicolumn{4}{|c|}{ Bradesco } & \multicolumn{4}{|c|}{ Itaú } & \multicolumn{4}{|c|}{ Unibanco } \\
\hline & Dec-97 & Dec-98 & Dec-99 & Dec-00 & Dec-97 & Dec-98 & Dec-99| & Dec-00 & Dec-97| & Dec-98 & Dec-99 & Dec-00 \\
\hline Operating efficiency* & $88.3 \%$ & $92.4 \%$ & $93.8 \%$ & $90.8 \%$ & $87.2 \%$ & $85.1 \%$ & $83.0 \%$ & $79.2 \%$ & $90.8 \%$ & $91.1 \%$ & $90.7 \%$ & $92.4 \%$ \\
\hline Cost-to-income ratio** & $75.7 \%$ & $72.3 \%$ & $78.4 \%$ & $76.4 \%$ & $78.9 \%$ & $74.7 \%$ & $73.9 \%$ & $67.6 \%$ & $73.8 \%$ & $67.5 \%$ & $64.9 \%$ & $68.8 \%$ \\
\hline Return on Average Equity (ROOE) & $14.9 \%$ & $16.0 \%$ & $16.3 \%$ & $21.5 \%$ & $17.1 \%$ & $25.6 \%$ & $30.5 \%$ & $25.6 \%$ & $16.4 \%$ & $15.6 \%$ & $14.8 \%$ & $18.5 \%$ \\
\hline Return on Average Assets (ROOA) & $2.0 \%$ & $2.1 \%$ & $2.0 \%$ & $2.7 \%$ & $2.0 \%$ & $3.3 \%$ & $4.4 \%$ & $3.2 \%$ & $1.7 \%$ & $1.7 \%$ & $1.9 \%$ & $1.8 \%$ \\
\hline Loans revenues/Financial revenues ${ }^{\star * *}$ & $67.7 \%$ & $65.6 \%$ & $63.9 \%$ & $63.3 \%$ & $67.3 \%$ & $44.3 \%$ & $45.9 \%$ & $47.7 \%$ & $69.4 \%$ & $59.5 \%$ & $68.3 \%$ & $64.2 \%$ \\
\hline Securities revenues/Financial revenues & $21.0 \%$ & $23.3 \%$ & $20.4 \%$ & $26.1 \%$ & $25.8 \%$ & $50.5 \%$ & $49.1 \%$ & $49.0 \%$ & $25.3 \%$ & $35.2 \%$ & $28.2 \%$ & $33.9 \%$ \\
\hline Fees revenues/Financial revenues & $20.5 \%$ & $18.7 \%$ & $16.9 \%$ & $27.7 \%$ & $41.6 \%$ & $22.9 \%$ & $31.5 \%$ & $32.3 \%$ & $18.4 \%$ & $16.7 \%$ & $15.6 \%$ & $19.2 \%$ \\
\hline
\end{tabular}

Source: Author's elaboration using data from the bank's balance sheets (only multiple banks)

Notes:( ${ }^{*}$ )Operating expenses (loans+securities+trade finance+compulsory deposits+services fees+income of subsidiaries)/Operating revenues (deposits+borrowings+provision for loan losses+salaries+overhead)

$\left.{ }^{* *}\right)($ Salaries expenses + Overhead)/(Gross margin of intermediation + Banking services fees + Provision for loan losses)

$\left({ }^{* * *}\right)$ Financial revenues $=$ loans + leases + securities + trade finance + compulsory deposits

The indicators show that, generally speaking, there is an overall increase in the performance of these banks but no clear tendency in the case of productivity. The latter can be explained by the short-term effect of the recent acquisitions. The average return on average equity of the Top 3 private domestic banks in 1997-2000 was around $19.0 \%$, much higher than the average return by $12.0 \%$ in the Brazilian banking sector in 1989-1993. Itaú, the second-largest private bank, seems to be the most efficient bank among the Top 3, at the same time that presents higher levels of profitability. Its strategy has been to be the leader in performance although its strategy has been conservative with low loan exposure and profitability based mostly on securities revenues (Table 5), taking advantage of the high rates of interest in Brazil during 1997-2000. Bradesco, the largest private bank in Brazil, increased its profitability (ROOE) from $16.9 \%$ in 1999 to $21.5 \%$ in 2000 . Revenue losses due to falling domestic interest rates in 2000 were more than compensated for by a $41 \%$ surge in credit and leasing operations, a $32 \%$ hike in funds under management and a $25 \%$ increase in deposits (The Banker, March 2001, p. 83). Unibanco, the forth-largest private bank, has had its profitability ratio not very high, and one cause is its high administrative expenses, which increased after the acquisition of Bandeirantes. Unibanco has traditionally

\footnotetext{
${ }^{20}$ One needs to be careful in doing some comparison using indicators of bank's productivity and performance, once, with the recent changes in banking industry, the mix of products of each bank varies a great deal.

21 'Unconsolidated' data involve only banking assets, while 'consolidated' data also involve assets of nonbank subsidiaries.
} 
occupied the middle tier of profitability among the large Brazilian banks, with overall returns on assets and equity slightly below those of Bradesco and Itaú. Thus, the recent data show some evidence that, unless for the recent period, Brazilian private banks are obtaining good performance and the costs if not decreasing have been unless under control.

\subsection{Domestic private banks versus foreign banks}

Table 6 includes some selected indicators concerned to the efficiency and performance of four private domestic banks (Bradesco, Itaú, Unibanco and Safra), four European banks (ABN-AMRO Real, HSBC, Sudameris and BBV) and two American banks (BankBoston and Citibank), with 'consolidated' data extracted from a recent and extensive report written by some banking analysts of BSCH (Guimarães, Monteiro \& Sanchez, 2001). Unfortunately, the report does not include data from Banco Santander do Brasil, the top foreign bank in Brazil. One needs to be careful with the comparison among banks, since although all banks are retail banks with a large branch network, their size differs a great deal. In fact, a very large bank in Brazil, such as Bradesco, has almost $11 \%$ of the banking market share, while a middle size bank, such as BBV Banco, has only $1 \%$ of the market share.

TABLE 6

Selected indicators - Some of the Bigger Brazilian Banks - 1999-2000

\begin{tabular}{|c|c|c|c|c|c|c|c|c|c|c|c|c|}
\hline & \multicolumn{6}{|c|}{ Efficiency } & \multicolumn{6}{|c|}{ Performance } \\
\hline & \multicolumn{2}{|c|}{$\begin{array}{l}\text { Index of } \\
\text { efficiency* }\end{array}$} & \multicolumn{2}{|c|}{$\begin{array}{c}\text { Employees/ } \\
\text { branches }\end{array}$} & \multicolumn{2}{|c|}{$\left(\begin{array}{c}\text { Net income/ } \\
\text { employees }\end{array}\right.$} & \multicolumn{2}{|c|}{$\begin{array}{c}\text { Return on } \\
\text { equity }\end{array}$} & \multicolumn{2}{|c|}{$\begin{array}{l}\text { Return on } \\
\text { assets }\end{array}$} & \multicolumn{2}{|c|}{$\begin{array}{l}\text { Net interest } \\
\text { margin }\end{array}$} \\
\hline & 1999 & 2000 & 1999 & 000 & 1999 & 2000 & 1999 & 2000 & 1999 & 2000 & 1999 & 2000 \\
\hline Bradesco & $70.41 \%$ & $65.62 \%$ & 7 & 7 & 20.6 & 32.0 & $16.32 \%$ & $21.50 \%$ & $1.38 \%$ & $1.83 \%$ & $7.19 \%$ & $7.12 \%$ \\
\hline taú & $66.12 \%$ & $66.54 \%$ & 15 & 16 & 49.6 & 50.9 & $31.65 \%$ & $27.71 \%$ & $3.60 \%$ & $2.65 \%$ & $7.56 \%$ & $7.09 \%$ \\
\hline Uniba & $69.44 \%$ & $70.10 \%$ & 13 & 18 & 31.6 & 36.0 & $14.76 \%$ & $13.43 \%$ & $.64 \%$ & $1.44 \%$ & $7.31 \%$ & $6.04 \%$ \\
\hline Safra & $61.40 \%$ & $54.16 \%$ & NA & 40 & NA & 88.5 & $19.33 \%$ & $22.11 \%$ & $1.10 \%$ & $1.32 \%$ & $4.91 \%$ & $4.01 \%$ \\
\hline ABN-Amro Real & $69.95 \%$ & $72.92 \%$ & NA & 15 & 9.2 & 13.3 & $10.32 \%$ & $5.47 \%$ & $1.04 \%$ & $0.93 \%$ & $6.34 \%$ & $13.17 \%$ \\
\hline$A S B C$ & $79.27 \%$ & $94.20 \%$ & NA & 13 & NA & 9.7 & $25.76 \%$ & $21.48 \%$ & $1.84 \%$ & $1.21 \%$ & $10.39 \%$ & $8.02 \%$ \\
\hline Sudameris & $130.5 \%$ & $105.5 \%$ & NA & 18 & -15.1 & -46.1 & $-14.85 \%$ & $-38.28 \%$ & $-0.73 \%$ & $-1.83 \%$ & $3.36 \%$ & $4.31 \%$ \\
\hline BBVA & $78.40 \%$ & $87.42 \%$ & NA & 12 & NA & 13.8 & $28.49 \%$ & $9.25 \%$ & $2.12 \%$ & $0.67 \%$ & $6.49 \%$ & $5.29 \%$ \\
\hline Ba & $49.41 \%$ & $52.78 \%$ & NA & 20 & NA & 131.0 & $22.23 \%$ & $20.57 \%$ & $1.19 \%$ & $1.16 \%$ & $8.27 \%$ & $5.83 \%$ \\
\hline Citibank & $38.25 \%$ & $76.30 \%$ & NA & 24 & NA & 92.8 & $48.45 \%$ & $19.37 \%$ & $4.02 \%$ & $1.43 \%$ & $11.79 \%$ & $3.95 \%$ \\
\hline
\end{tabular}

Source: Author's elaboration with data from BSCH (2001)

Notes: $\left(^{*}\right)$ Efficiency index $=($ salaries + overhead + fees $) /$ net interest income

The indicators of efficiency in 1999-2000, in particular the index of efficiency and the ratio 'net income/employees', present a picture in which the domestic banks had in average a slight improvement in these indicators, and a better index in comparison with foreign banks, although the subset of American banks - Citibank and Bank Boston presents a better performance than the subset of European banks. One needs to be careful in analysing these data. First, because the Top 3 domestic banks, as we have already stressed, are big retail banks, what permit them, ceteris paribus, to reap the benefits of economies of scale and scope. Second, because when one compares the European banks with American 
banks he/she has to consider the fact that the latter ones have their business very focused in a selected segment of the retail market - private banking and corporate banking - as well as the fact the they did not participate of the recent wave of acquisitions in Brazil and thus they don not have problems concerning to the absorption of new banks.

Finally, according to the ratios ROOE and ROOA, the performance of the domestic banks, with the exception of the Unibanco, is better than the performance of the foreign banks. Again there are differences results if we compare the subset European banks with American banks, since the latter shows a better performance in 1999-2000. The best performance of the domestic banks can be explained partially by the fact they have a bigger customer basis, what provide them a cheaper funding in order to support their operations in the asset side (Guimarães et alii, 2001). Probably they reap the benefits of the economies of scale and scope, but there is no study measuring these economies in Brazilian banking sector. Summing up, even though the evidences do not permit to extract final conclusions concerning to the recent behaviour between domestic and foreign banks, there is some evidence that overall the top private domestic banks in Brazil presented unless in 19992000 better results in the banking indicators than the foreign banks.

\section{Conclusions}

The main conclusions of this paper are:

a) Both from historical-empirical and theoretical-analytical point of view there are strong reasons to believe that it is in operation, to a greater extent as an international phenomenon, a process of consolidation in banking industry, as a result of both financial deregulation and technological changes. The new phase of banking internationalisation is a consequence of this process, in which increasingly the financial institutions seek to diversify their activities - in terms of products and services, and/or geographically - and increase their minimum scale necessary to remain competitive.

b) The process of restructuring of the banking sector in euro area is becoming intensive. Increasing abroad for some European banks is not only a source of diversification earnings but also a mean that they have found to strengthen for the competition environment in euro zone. The Latin American strategy may be interpreted as a response to this more competitive environment, in which several factors are eroding income from traditional banking business.

c) There are some evidences that, unless in the case of the Top 3 private domestic banks, Brazilian banks have been reacting positively the entry of the foreign banks, since they have been participating actively of the wave of acquisitions, and have been improving their efficiency and performance. In fact, domestic private banks have some advantages on foreign banks that they can explore, once, as they have been since a long time in Brazil, they are more adapted to the peculiarities of Brazilian banking market. Cultural differences and the high level of development and sophistication of banking sector in Brazil that resulted from its capability to adapt to the period of high inflation may explain this behaviour.

\section{References:}

Aliber, R.Z. (1984). "International banking: a survey". Journal of Money, Credit and Banking vol. 16, no. 4, November. 
Belaisch, A., Kodres, L., Levy, J., Ubide, A. "Euro-area banking at the crossroads". IMF Working Paper 01/28. Washington: IMF.

Berger, A.N., DeYoung, R., Udell, G.F. (2000). "Efficiency barriers to the consolidation of the European financial services industry". (forthcoming in Brookings-Wharton Papers on Financial Services, vol. 3, 2000).

Berger, A.N., DeYoung, R., Genay, H., Udell, G.F. (2000). "Globalization of financial institutions: evidence from cross-border banking performance" (forthcoming in European Financial Management vol. 6, 2000).

BIS (1996). 66th Annual Report. Basel, Bank for International Settlements.

BIS (1999). BIS Quarterly Review. Basel, Bank for International Settlements, August.

BIS (2000). 70th Annual Report. Basel, Bank for International Settlements.

Calderón, A. \& Casilda, R. (2000). "La estrategia de los bancos españoles en América Latina". Revista de la CEPAL, no. 70, April.

Carvalho, F.C. (2001). "The recent expansion of foreign banks in Brazil: first results". Paper presented in the workshop "European Banks and the Brazilian Financial System", Centre for Brazilian Studies, University of Oxford, 12/3/2001.

Claessens, S., Deminguc-Kunt, A. \& Huizinga, H. (1998). "How does foreign entry affect the domestic banking market”. Unpublished manuscript.

Deminguc-Kunt, A. \& Huizinga, H. (1998). "Determinants of commercial bank interest margins and profitability: some international evidence". World Bank Discussion Paper n. 1900, March.

ECLAC (2000). Foreign Investment in Latin America and the Caribbean - 1999 Report. Santiago: Chile.

ECLAC (2001). Foreign Investment in Latin America and the Caribbean - 2000 Report. Santiago: Chile.

European Central Bank (2000). "Merger and acquisitions involving the EU banking industry: facts and implications", http://www.ecb.int

Focarelli, D. \& Pozzolo, A. F. (2000). "The determinants of cross-border bank shareholdings: an analysis with bank-level data from OECD countries". Unpublished manuscript.

Freitas, M.C. (1999). “Abertura do sistema bancário ao capital estrangeiro”. In Freitas, M.C. (org.), Abertura do Sistema Financeiro no Brasil nos Anos 90. São Paulo: IPEA/Fapesp.

Grubel, H. (1977). "The theory of multinational banking”. Banca Nazionale del Lavoro Quarterly Review no. 123, December.

Guillén, M.F. \& Tschoegl, A.E. (1999). "At last the internationalization of retail banking? The case of the Spanish banks in Latin America". Working Paper no. 99-41. Philadelphia, The Wharton School/University of Pennsylvania.

Guimarães, P., Monteiro, F., Sanchez, A. (2001). "Brazilian banking system: state, public and private - a complete travel kit to survive in Brazilian banking". Latin American Equity Research. São Paulo: Santander Central Hispanico Investment.

Kregel, J. (2001). "European bank concentration in the light of US experience". Paper presented in the workshop "European Banks and the Brazilian Financial System", Centre for Brazilian Studies, University of Oxford, 12/3/2001.

Molyneux, P. (2000). "Does size matter? Financial restructuring under EMU”, Unpublished manuscript.

Nellis, J. et alli (2000). "Strategic challenges for the European banking industry in the new millennium". International Journal of Bank Marketing, vol. 12, no. 2.

Sebastian, M. \& Hernansanz (2000). "The Spanish bank's strategy in Latin America", SUERF Studies no. 9.

Williams, B. (1997). "Positive theories of multinational banking: eclectic theory versus internalisation theory”. Journal of Economic Surveys, vol. 11, no. 1. 